論文

\title{
継時呈示における等色繰り返し精度に対する時間ギャップの影響
}

\author{
正会員 篠 田 博 之（京都大学）専門会員 池 田 光 男 (京都大学)
}

\section{Color Matching Repeatability as a Function of Time Interval in Successive Presentation.}

Hiroyuki Shinoda (Member)

Mitsuo Ikeda (Fellow Member) (Kyoto University)

\begin{abstract}
A color matching task was done by one subject repeatedly to study color discriminability as a function of inter stimulus interval (ISI) in successive stimuli presentation. Reference and matching stimuli were presented alternately with a certain ISI $(0-1000 \mathrm{msec}$.) The subject adjusted the color of the matching stimulus to match the color of the reference stimulus while switching their presentation at will. The distribution of matching points was assessed by an ellipsoid in xyY color space. The size of the ellipsoid was constant in spite of the ISI increase, but was nevertheless larger than that obtained in simultaneous presentation. The fact shows that the time interval between successive fixations was not a primary factor of low discriminability for spatially separated stimuli.
\end{abstract}

KEYWORDS : color discrimination, color matching, stimuli separation, gaze shift, time interval and color memory.

\section{1.はじめに}

色差知覚や色弁別能力は刺激呈示の物理的パラメー夕に依存军 る。過去の研究から刺激の配置, 特に刺激間の空間的なギャップ が色弁別能力を低下させることが明らかになっている゙', しかし ここで扱われているギャップ流視角で数度以内が殆どである。と ころが普段我々は空間的に広範囲に分布した物体の色を比較して おり，時には比較対象が同一視野にないこともある。そのような 状況では, 眼球運動や頭部回転により視点を移動しながら, 動的 に外界を観察しなければならない。

以前我々は大きな視点移動を伴う状況での色弁別能力を調べる ために，2 刺激の間隔を変えて等色の繰り返し精度を測定した 刺激間隔（中心間の距離）を $6^{\circ}$ から $120^{\circ}$ の範囲で変化させたとこ ろ, 間隔の増大に伴って $60^{\circ}$ 付近までは精度が低下し, それ以上で はほぼ一定となる傾向を示した。図 1 にその結果を示す。縦軸は xyY 色空間 (CIE1931xy 色度平面に輝度軸 $Y\left(\mathrm{~cd} / \mathrm{m}^{2}\right)$ が直行卞 る空間）における95\%等色楕门体の，中心を通る等輝度断面での 楕门面積である。ただし面積の平方根を，60での值 $\mathrm{A}_{6}$ に対する相 対值で表示した。

色弁別や等色作業には細かい色の差を見分ける能力が反映され るため, 色知覚特性の良い網膜中心筒の色情報が重要な意味を持 つ.もしも網膜中心窝の物理的条件だけで色弁別間值が決まるな ら，刺激の空間的な間隔を変えたときの色弁別能力の変化は視点 移動に要する時間，つまり刺激呈示の時間間隔で説明できる。

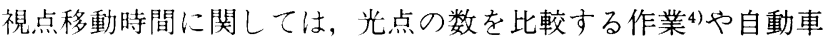
運転中5の視点の解析結果から，移動量に対して線形に増大する との報告がある。しかし等色作業あるいは色弁別作業中の視点移 動を解析した研究はない。 そこで次に我々は, 等色作業中の視点 の動きを計測し, 視点移動に要する時間を求めた6). 結果を図 2 に 示寸。横軸が視点移動量 $(\Delta G)$, 縦軸が移動時間 $(\Delta T)$ である.

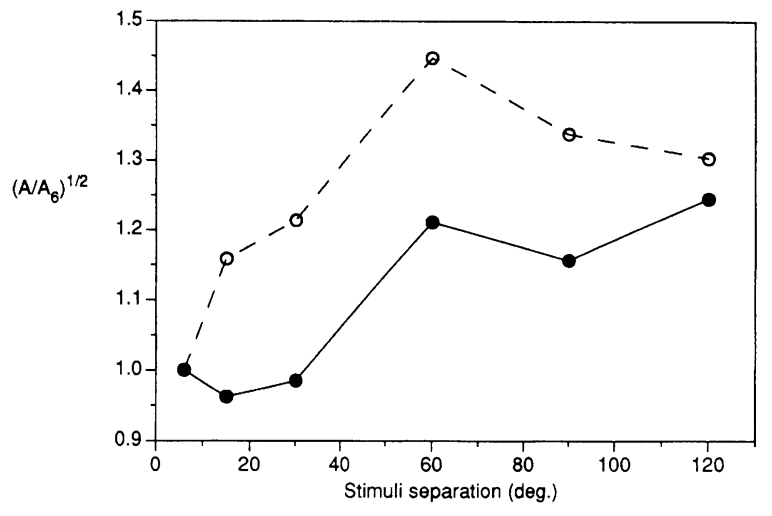

図 1 空間的な刺激間隔の関数としての等色棈円面積 $\mathrm{A}^{3)}$ 。

横軸汁刺激の中心間距離, 縦軸纺刺激間隔 $6^{\circ}$ の值 $\mathrm{A}_{6}$ に対㐫る相対値の平方根

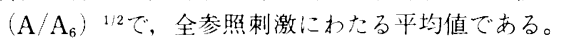

$\mathrm{O}$ : 被矣者 HS, ○ : TI。

Figure 1 Mean square root of area of color matching ellipses $A^{1 / 2}$ as a function of spatial separation. ${ }^{31} \mathrm{~A}_{6}$ is area of ellipse obtained in $6 \mathrm{deg}$. separation. $\bigcirc$, subject HS: $\bullet$, TI. 


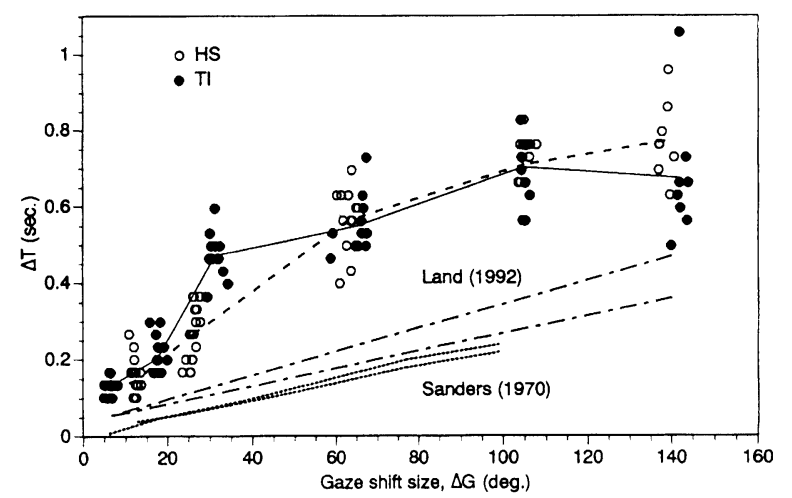

図 2 視点移動量 $\Delta G$ と移動に要する時間 $\Delta T^{6)}$ 。

$\mathrm{O}$ : 被験者 HS, O : TI。平均值を折れ線で示す。

Figure 2 Gaze shift size $(\Delta \mathrm{G})$ and duration taken for gaze shift $(\Delta \mathrm{T})^{6 \text { ) }}$. $\bigcirc$, Subject HS ;, TI.Lines indicate average values.

移動量の増大に伴って移動時間は上昇するが, 後半で飽和する傾 向が見られる.

色弁別の時間特性に関する研究としては，恒常法によるもので Uchikawa et al. ${ }^{7}$, Romero et al..$^{8)}$ ，等色法では

Uchikawa et al. ${ }^{9)}$, Newhall et al. ${ }^{10)}$ ，等がある。いずれも同時 比較時に比べて継時比較時の色弁別能力は低いことが示されてい る. Uchikawa et al.7)では 2 刺激の時間間隔は SOA (stimulus onset asynchrony，片方の刺激の呈示開始からもう一方の刺激の 呈示開始までの時間間隔）で $0 \sim 5450 \mathrm{msec}$.であるが呈示時間が $110 \mathrm{msec}$.と等色作業中の注視時間に比べて極端に短い. その他の 研究では時間間隔が 5 秒以上であり, むしろ色記憶の領域に入る と思われる。またどれも観察が 1 回だけであるとか呈示時間が決 められているなどの制限がある。

そこで本研究では被験者が自由に観察できる状況を実現し, 刺 激呈示の時間的ギャップを変えて等色の繰り返し精度を測定す る。そして刺激が空間的に離れているときに見られる色弁別能低 下の原因が,視点移動による時間的ギャップにあるのか確かめる.

\section{2. 実験}

\section{1 装置}

図 3 に装置の概略を示す。等色刺激呈示用のバーン八ム色彩計 と参照刺激呈示装置は, ともに $150 \mathrm{~W}$ の八ロゲンランプの光源と 色フィルタにより構成されている。装置は基本的には篠田ら ${ }^{3} に$ 記述の装置と同一であるが, 呈示時間を制御するためのシャッ夕， 拈よび夕イマ部が増設されている。シャッ夕は，それぞれ色彩計 中のウェッジフィル夕直前, 参照刺激呈示装置中の色フィルタ手 前に配置された。参照刺激と等色刺激の中心間の距離は $6^{\circ} \sim 120^{\circ}$ の範囲で設定できる. 被験者は色彩計の 3 つのノブと刺激呈示を コントロールするボタンを操作する。

\section{2 呈示条件}

被験者から刺激までの距離は約 $50 \mathrm{~cm}$. 参照刺激, 等色刺激はと もに一辺 $2^{\circ}$ の正方形で, 中心間の間隔は $6^{\circ}$ に固定されている。ブ 一ス内は無照明で，両刺激は光源色モードの見えになる。刺激の 呈示条件を図 4 に示す。一つは継時呈示条件である。始等色刺 激のみが呈示されているが, 被験者がボタン ON と同時に等色刺 激が消之, ある時間の後, 参照刺激が呈示される. ボタン ONの 間, 参照刺激は呈示され続ける。ボタンを離すと同時に参照刺激 が消之，またある時間間隔の後に等色刺激が呈示される。被験者 は等色するまでこれを繰り返す。観察時間は被験者が自由にコン
トロールできるため，2 刺激の時間間隔は SOA (stimulus onset asynchrony)ではなく, ISI (inter stimulus interval, 片方の刺激 の呈示終了からもう一方の刺激の呈示開始までの時間間隔）で定 義する必要がある。したがって本研究では刺激呈示の時間間隔お よび時間ギャップという語はこの ISIを指すものとする，時間間 隔 (ISI) は視点移動に要する時間と同程度とするため, 篠田ら ${ }^{6)}$ 参考に0，50，100，150，200，400，600，800，1000msec.の 9 条 件とした。もう一つの呈示条件は同時呈示であり，ボタンを押し ても参照刺激が呈示されるだけで等色刺激は消之ない。篠田ら

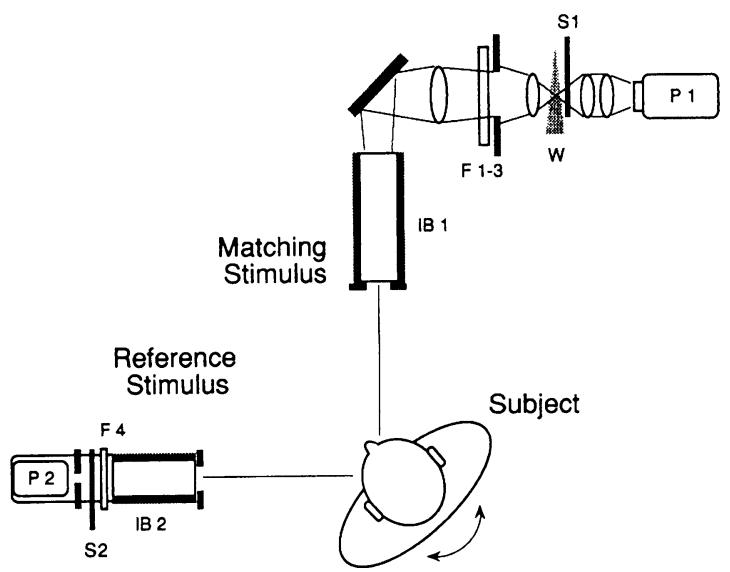

図 3 実験装置の概略図。

$\mathrm{P} 1, \mathrm{P} 2$ ：スライドプロジェクタ, F1- 3,F4：色フィル夕, IB1,IB2：積分管, $\mathrm{W}$ ：NDウェッジフィルタ, S1, S2：シャッタ。詳細は参考文献(3)に記述され ている。

Figure 3 Schematic diagram of the apparatus.

P1 and P2, projectors ; F1-3 and F4, color filters ; IB1 and IB2, integrat ing bars: W, ND wedge filter ; S1 and S2, shutters. For more details, see reference 3

Successive Presentation with Inter Stimulus Interval (ISI) $|S|=0,50,100,150,200,400,800,800,1000$ (msec)

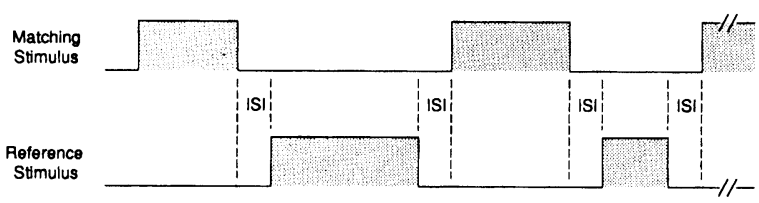

\section{Simultaneous Presentation}

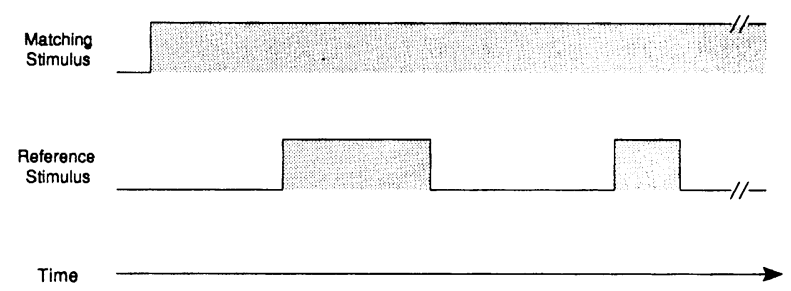

図 4 刺激の時間呈示条件。

Figure 4 Time course of stimuli presentation.

の刺激間隔 6 。等価な条件であり, コントロールとしてこの条件 を加えた，以上，刺激呈示条件は全部で10条件となる。

\section{3 刺激、被験者}

参照刺激は篠田ら ${ }^{3)}$ と同一の Yellow-Green, Orange, Purple と 今回新たに加えた Achromaticの 4 種類である。

Achromatic にはフジフィルム社製の色フィルタ ND-0.7 ( 1 枚) 
と LBB-2（2 枚）の計 3 枚を重ねて用いた。ミノル夕社製色彩計 CS-100による，実験終了後の測色值を表 1 に示す。

被験者は27才の男性 HS 1 名で, 篠田ら ${ }^{3)}$ の実験に参加した被 験者の一人である.

表 1 参照刺激の測色值（CIE1931xy 色度座標，および輝度）。 Table 1 Colorimetric value for the reference stimuli.

\begin{tabular}{cccc} 
参照刺激 & $\mathrm{x}$ & $\mathrm{y}$ & $\mathrm{Y}\left(\mathrm{cd} / \mathrm{m}^{2}\right)$ \\
\hline Yellow-Green & 0.396 & 0.543 & 179.0 \\
Orange & 0.616 & 0.355 & 39.7 \\
Purple & 0.380 & 0.212 & 46.2 \\
Achromatic & 0.396 & 0.401 & 51.1 \\
\hline
\end{tabular}

\section{4 手 順}

測定は篠田ら ${ }^{3)}$ と同様の手順に沿って行なわれた。被験者はブ 一ス内で数分間の暗順忘の後, 等色作業を開始する。等色が終了 したら実験者は色彩計の読みを記録する。その後, 被験者は自分 で等色在崩し, 次の等色作業に入る。等色は 5 回続けて繰り返す (1ブロック).1ブロックが終了したら参照刺激を取り替えて同 様の作業を行なう。1 セッションは 4 種類の参照刺激に対する等 色 (4ブロック)で構成され, セッション内の呈示条件およびISI は一定とした。各参照刺激，各呈示条件に対し計50回の等色とな
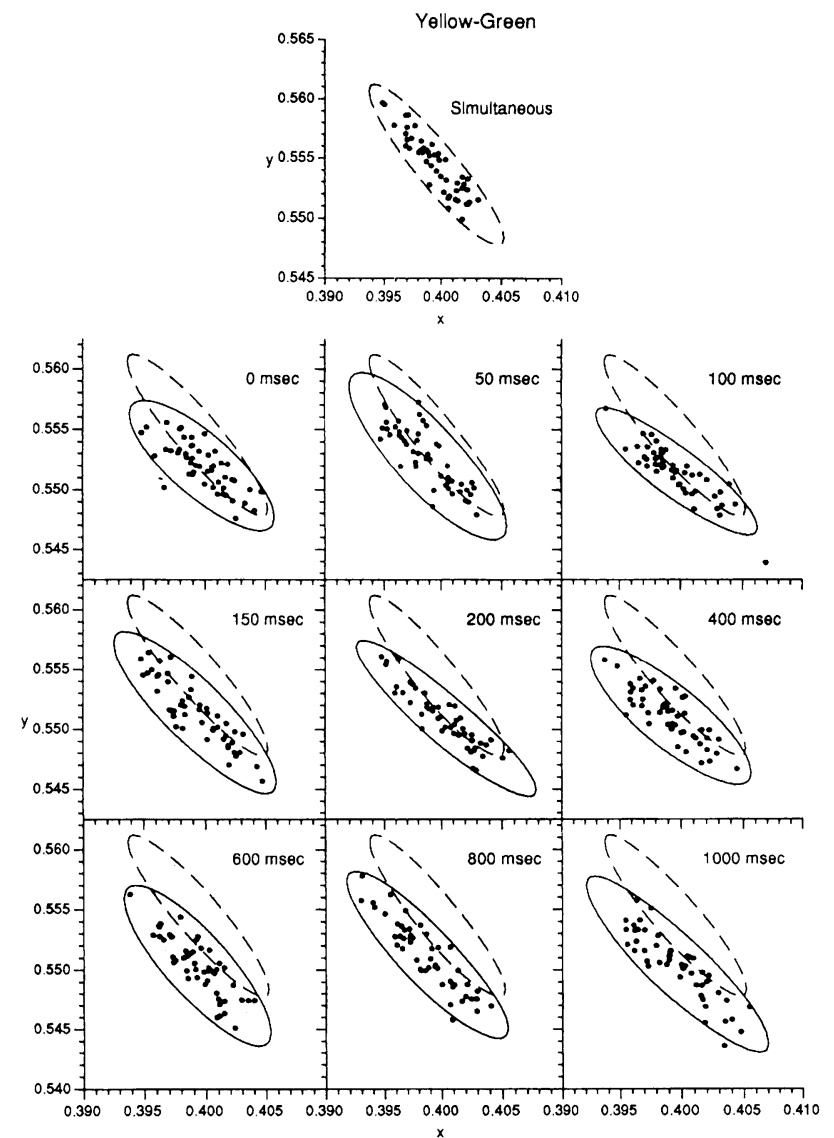

図 5 参照刺激 Yellow-Green に対する等色棈円体。

黑点: 等色点の $\mathrm{xy}$ 色度平面への投影, 楕円は等色楕门体の中心を通る等輝度 断面, 破線：同時呈示条件, 実線：継時呈示条件。被験者 HS。

Figure 5 Color matching ellipsoids for reference Yellow-Green. Dots, projection of matching points to $\mathrm{xy}$ chromaticity plane.

Ellipses, cross sections of ellipsoids at the constant-luminance plane through the center. Dashed lines, simultaneous presentation ; solid lines, successive presentation. Subject HS.
るように，全部で100セッションの実験を行った。

\section{3. 結 果}

\section{$3.195 \%$ 等色棈円体}

色彩計の読みから $(\mathrm{x}, \mathrm{y})$ 色度座標值, 輝度值 $\mathrm{Y}\left(\mathrm{cd} / \mathrm{m}^{2}\right)$ に 変換し, $\mathrm{x}, \mathrm{y}, \mathrm{Y} の$ 各ブロック毎の平均值と全体50回の平均値 を計算守る。ささらに各ブロックの平均值が全体50回の平均值に重 なるように各ブロック毎に 5 点を xyY 空間内で平行移動する。平 行移動後の等色点に対し統計処理を施し，3 次元の正規確率分布 で近似する。そして $95 \%$ の確率分布を包括するように棈円体を決 定する。デー夕処理および等色棈円体の導出方法は篠田ら゙に詳 細に記述されている。

得られた全等色点と棈円体を図 5 〜 8 に示す。一番上のグラフ は同時呈示条件によるもの，下のグラフは継時呈示条件によるも のである.いずれの楕円も楕円体の中心を通る等輝度での断面で, 点は等色点の $\mathrm{xy}$ 平面への投影を示す。また比較のため, 継時提示 条件のグラフに，同時提示条件の楕円を破線で表示した。困 5 は Yellow-Green に対する等色の結果であるが，条件に依らず棈円 の向きに大きな変化は見られない。また同時呈示条件と ISI 100 msec. 条件で僅かに等色点が密に分布している程度で, 楕円体の 大きさも殆ど変化していないと言える。困 6 の Orange では同時 呈示条件の楕円が明らかに小さい，棈円近似の弱点であるが，正 規分布を仮定するために，得られる棈円体は中心から遠く離れた 1 点の影響を受忛易い. 特に ISI $400,800,1000 \mathrm{msec}$.条件で棈

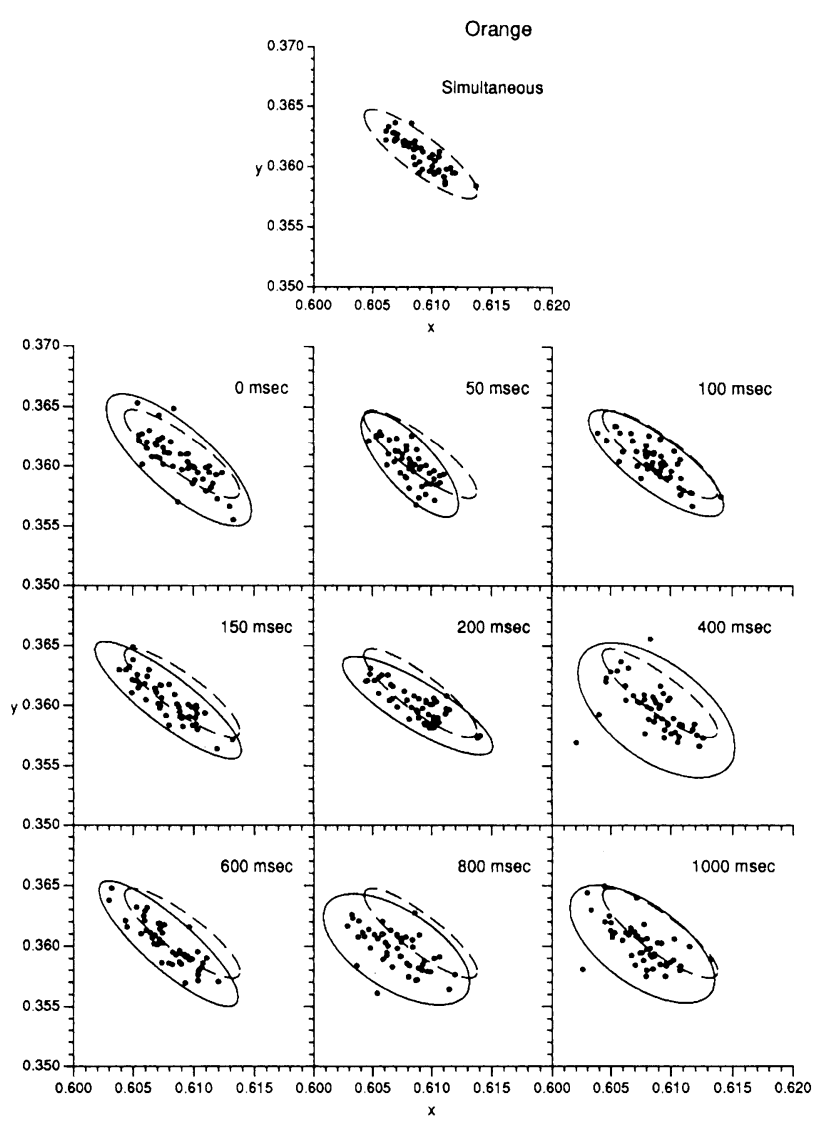

図 6 参照刺激 Orange に対する等色棈円体。

Figure 6 Color matching ellipsoids for reference Orange. 
円が大きくなっているのはこのためである。四7の Purpleでも 同時呈示条件の楕円が他に比べて小さい. ISIによって, 棈円の大 きさに変化はあるが，システマティックなものではない，図8 は Achromaticであるが, 棈円の向きが一定していない.これは等色 点分布に偏りが少ない，つまり円に近い分布をしているからであ ろう。大きさには大きな変化は見られない。ただし，他と同様に 同時呈示条件の楕川が小さい.

\section{2 等色中心位置}

楕円体中心，つまり等色中心位置の変化にある傾向が見られた ので図 9 にそれを示古。楕问は同時呈示条件のもので，中心点を 同時呈示, ISI $0 \mathrm{msec}$, $50 \mathrm{msc}$. $100 \mathrm{msec}$. 一順に折れ線 で結んでいる. Yellow-Green では同時旺示から継時呈示, さらに ISIの増大に伴って等色位置が y 座標減少の方向に移動してい る. Orangeでは左下方向つまり $\mathrm{x} ， \mathrm{y}$ とに小さくなる方向に， Purpleではその逆方向に, Achromaticではyの減る方向に各々 移動している，変化の大きさは僅かで，棈円を大きく外れるもの ではない。図 9 の下段に変化方向在矢印で示したが，これを見る と中心位置は彩度低下の方向に移動していることが分かる. 輝度 方向に関しては殆ど変化が見られなかったので四は割愛する。こ れとは逆に, Newhall et al. ${ }^{10) て ゙ は, ~}$ 同時等色に比べて記憶等色 のときは高い彩度で等色している。また，我々でも空間的なギャ ップを変えたときには今回のような傾向は見られなかっだ). 本 実験も被験者 1 人だけであり，低彩度方向に移動するという傾向 が一般的とは断定できない.

\section{3 等色棈円体の大きさ}

等色の繰り返し精度を与之る指標として95\%等色棈円体の体積 $\mathrm{V}$, 中心を通る等輝度断面の楕円面積 $\mathrm{A}$, 輝度軸方向の径 $\mathrm{dY}$ を考 える。図10に体積 $\mathrm{V}$, 面積 $\mathrm{A}$, 径 $\mathrm{dY}$ を ISIの関数として表示した。 上段のグラフでは值そのものを縦軸にとっている。シンボルの違 いで参照刺激の違いを表わしている。また白抜きのシンボルは同 時呈示条件を表わしている。（A）の棈円面積Aでは, ISIによっ て值の上下はあるが, 変化に一貫した傾向は見られない.しかし， いずれも同時呈示 (白抜きシンボル)の方が継時呈示 (黒シンボ ル）に比べて低い值走している。この継時比較での弁別能力の 低下は過去の研究報告と一致与る。(B)注等色楕门体の輝度軸方 向の径 dYであるが, Yellow-Greenだけ值が高い。これは刺激輝 度がそもそも高いためで, 楕円体中心の輝度值 $\mathrm{Y}$ との比 $\mathrm{dY} / \mathrm{Y}$ で 見れば他と変わらない。ここでも面積同様, ISIによる変化は見ら れない.しかし継時呈示と同時呈示の差は一貫していない. PurpleやAchromaticでは同時呈示の方が低く, 逆に Yellow-Green では高い值を示している（C）の楕円体体積Vにおいても，ISIに よる值の上下はあるが一貫した変化は見られない。また，いずれ も同時呈示の方が低い值になっている。どのグラフも参照刺激に よって值にかなりばらつきがある。そこで次に同時呈示で得られ た值を基準にして相対的にプロットした。下段にそれを示す。縦

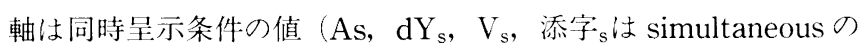
意)で割った相対值である。また体積, 面積は次元を揃えるため, 各々 $1 / 3$ 乗， $1 / 2$ 乗とした。これらのグラフを見ると，相対值表示 では参照刺激による差が小さくなるということが分かる。特に，

（E）でその効果が大きい.（B）の Yellow-Greenの100msec.で 見られる落ち込みも（E）では目立なない。下段のグラフでは参 照刺激による差が小さいので, 平均值を求め, 值を折れ線で結ん だ。ただしシンボルは表示していない（D）の棈円面積では全て 1 以上の值になった。これは先に述べた通り, 同時呈示の方が楕

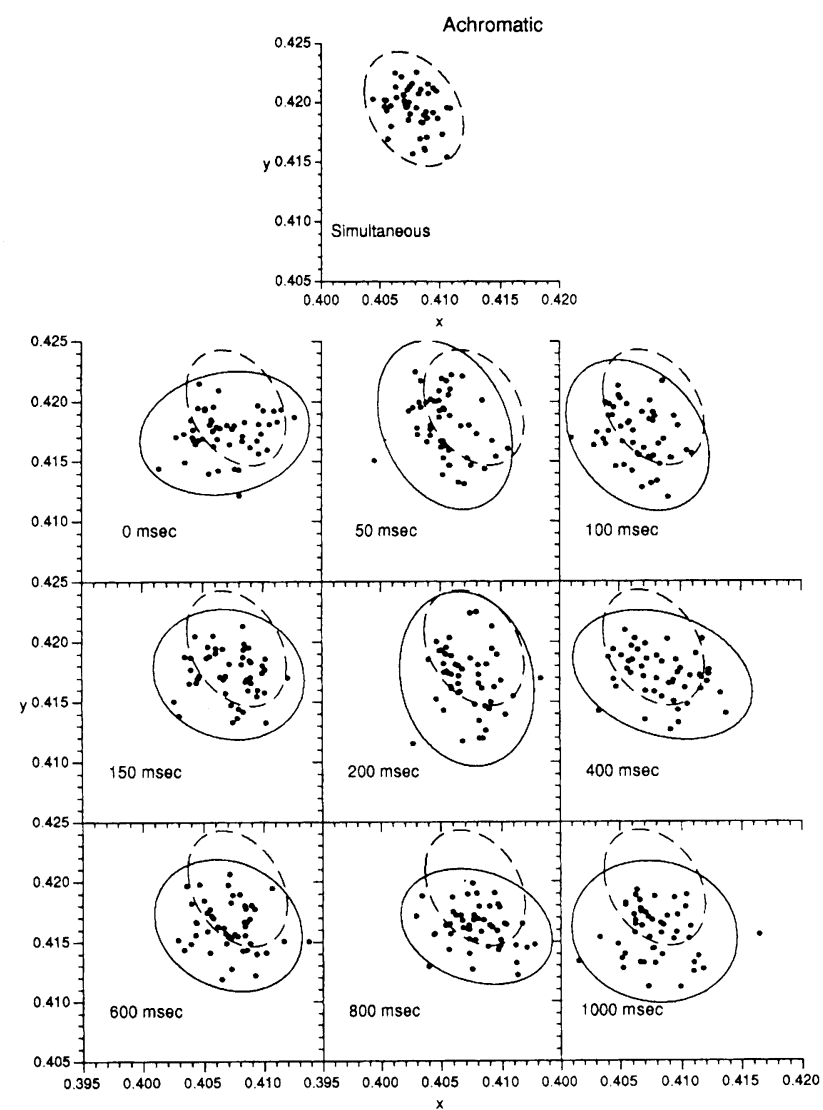

図 7 参照刺激Purpleに対する等色棈円体。

Figure 7 Color matching ellipsoids for reference Purple.
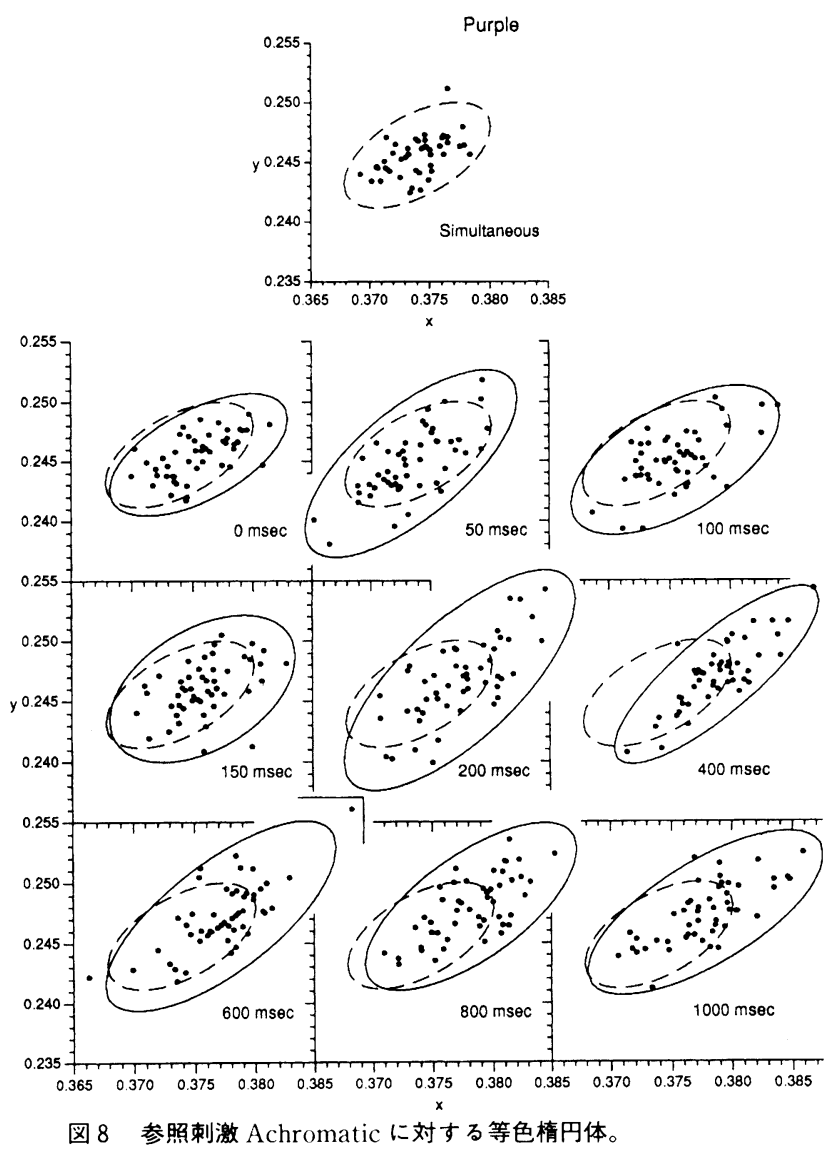

Figure 8 Color matching ellipsoids for reference Achromatic. 

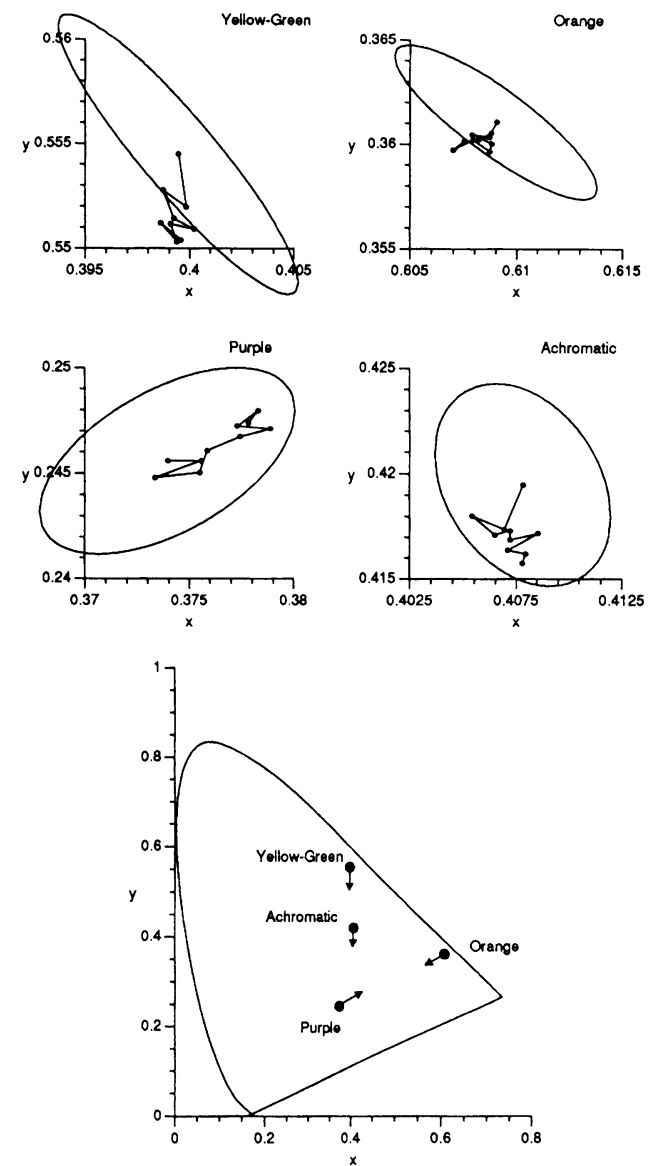

図 9 等色中心位置の変化。

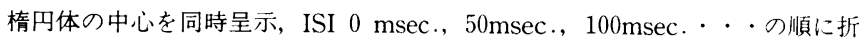
れ線で結んでいる。棈円は同時呈示で得られたもの。下段にずれの方向を矢印 で示した。

Figure 9 Shifts of center of the ellipsoids.

The centers are connected by lines in order of ISI. Ellipses are obtained in simultaneous presentation. The arrows show the shifts direction.
円面積が小さいことを示している，継時呈示においてはISIによ る影響は見られず，平均值は 1.4 付近でほぼ一定となっている.

(E) では殆どの点が 1 付近に分布しており同時呈示と継時呈示 で差がないことを示している。平均值も約 1 で ISI に依らず一定 である。（F)では Yellow-Green の $100 \mathrm{msec}$. 以外，1 以上になっ ている．またISIに依らず一定（平均值は約1.3）の傾向を示して いる，以上から，次のことが示される，楕円面積、つまり色度弁 別に関しては同時呈示に比べて継時呈示での弁別能力は低い。し かし, 継時呈示においてはISIの大小に依らず色度弁別能力は一 定である.また, ISI $0 \mathrm{msec}$. 条件と同時呈示条件との差は, こ の色度弁別能力の低下が時間条件の違いによるものではなく，網 膜周辺の条件の違い（片方の刺激を観察しているときに，もう一 方の刺激が呈示されているかどうかの違い）によるものであるこ とを示している $\mathrm{dY}$ の輝度弁別に関しては, 同時と継時の差はな い.また継時呈示においては，時間的ギャップ (ISI)の大小に関 係なく，輝度弁別能力は変わらない。

\section{4. 考 察}

\section{1 等色中心位置に関して}

同時呈示から継時呈示, さらに時間的ギャップ (ISI) の増大と いう変化に伴って, 等色する点は僅かに彩度の低下する方向にず れる.この等色点のずれは, 色記憶に関する過去の研究報告10)とは 逆の方向である。また、ずれの大きさもかなり小さい。記憶実験 のよjに 1 回の観察だけならば，記憶での色のずれが生じる可能 性はある。しかし，今回のように自由に何回でも観察できる状況 ではずれは起こりにくいと考えられる。それでも僅かにずれが生 じたということは, 比較作業が等色刺激から参照刺激, 参照刺激 から等色刺激というように双方向的に行なわれていない可能性が

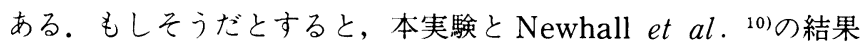
を考之併せて，まず(1)等色刺激を観察し記憶する，次に(2)参照刺 激を観察し記憶した色と比較する，そして(3) (2)で得た印象を基 にして調色，という順序が優勢であると予想される。しかし，被 験者 1 人だけの結果であり，これ以上の考察は本研究の主題から
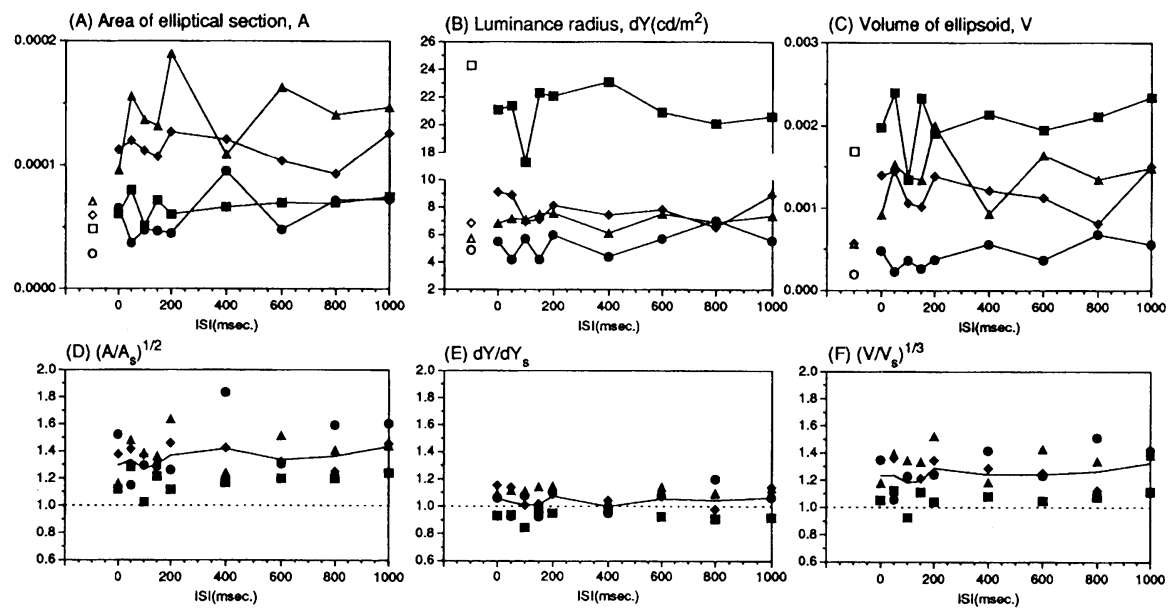

図10 ISI の関数としての等色棈円体の大きさ变化。

(A) 棈円面積 $\mathrm{A}$ ，(B) 輝度軸方向の径 $\mathrm{dY}$ ，(C) 椿円体体積 $\mathrm{V}$ ，(D) 楕山面積 $\mathrm{A}$ の同時呈示での值 $\mathrm{A}_{\mathrm{s}}$ に対方る相対值の平方根 $\left(\mathrm{A} / \mathrm{A}_{\mathrm{s}}\right)^{1 / 2}$, (E) $\mathrm{dY}$ の 同時呈示 $\mathrm{dY}_{\mathrm{s}}$ に対する相対值 $\mathrm{dY} / \mathrm{dY} \mathrm{s}$, (F)棈円体体積の相対值の立方根 $\left(\mathrm{V} / \mathrm{V}_{\mathrm{s}}\right)^{1 / 3}$ 。黒シンボルは継時呈示での值, $\mathbf{\square}$ : 参照刺激 Yellow-Green,

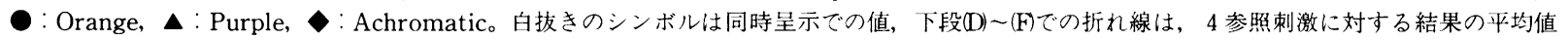
を示す。

Figure 10 Size of the ellipsoid as a function of ISI

(A) Area of ellipses $A$, (B) luminance radius $d Y,(C)$ volume of ellipsoids $V$, (D) relative value of $A^{1 / 2}$ to that for simultaneous presentation

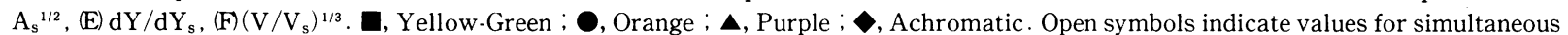
presentation. Lines show average values for all references in $(D),(E)$ and $(F)$. 
外れることになるので，等色点のずれに関してはまた機会をあら ためて実験を設定し，検討することが必要である。

\section{2 等色の繰り返し精度に関して}

等色の繰り返し精度として95\%等色楕円体の体積 $\mathrm{V}$, 等輝度断

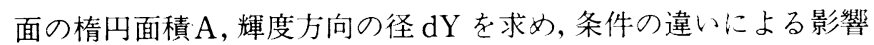
を検討した，継時呈示条件においては等色楕円体の大きさに時間 的ギャップ (ISI) の影響は見られなかった。しかし，楕円面積 A

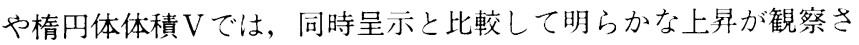
れた. 輝度方向の径 $\mathrm{dY}$ で差がでなかったのは, 輝度弁別は継時呈 示条件でも同時呈示条件と同程度の能力であることを示してい る.一方 Uchikawa et al.${ }^{9}{ }^{9}$ は継時比較での輝度弁別能力の低下を 報告している。その実験では 2 刺激は二分視野として，空間的に 隣接配置されている。しかし今回の実験ではすでに刺激間に $6^{\circ} の$ 空間的ギャップがあり，この違いが結果に影響している可能性が ある。また，この特性は被験者 HSに特有であるとも考之られる。 というのは，空間的ギャップの影響を調べた実験了でも， d 化は他の被験者と比較して小さかったからである。

図10の (A) および (D)に示されるように, 楕円面積 Aの結果に おいて, 同時呈示に比べて継時呈示での色度弁別能力が低下して いたことは過去の報告ア 10 と一致している。しかしISIの大小に 関係なく一定という事実は「刺激と刺激の時間間隔は色度弁別能 力に影響しない」ことを示している. 継時呈示の ISI $0 \mathrm{msec}$. 条 件と同時呈示条件との物理的条件の違いは, 網膜中心窩で片方の 色刺激を観察しているときに，網膜周辺部に比較对象となるもう 一方の色刺激が呈示されているかどうかだけである。従ってこの 2 条件間に見られた色度弁別間值の差は「弁別能力に影響を与之 るのは呈示の時間条件の違いではなく, 網膜周辺の条件の違いで ある」ことを示唆している。

\section{3 空間的ギャップと時間的ギャップ}

視点移動による時間的ギャップが，刺激が空間的に離れている ときに見られる色弁別能力低下の主要因ではないことは，ここま での考察から明らかである。図11に空間的ギャップに対する楕円 面積の変化を示寸被験者 HSのデー夕（図1の白抜きシンボル） を, 同じく被験者 HSの視点移動時間 $\Delta \mathrm{T}$ の值（図 2 の破線の縦 軸値）を横軸として再プロットし，時間的ギャップ効果のグラフ

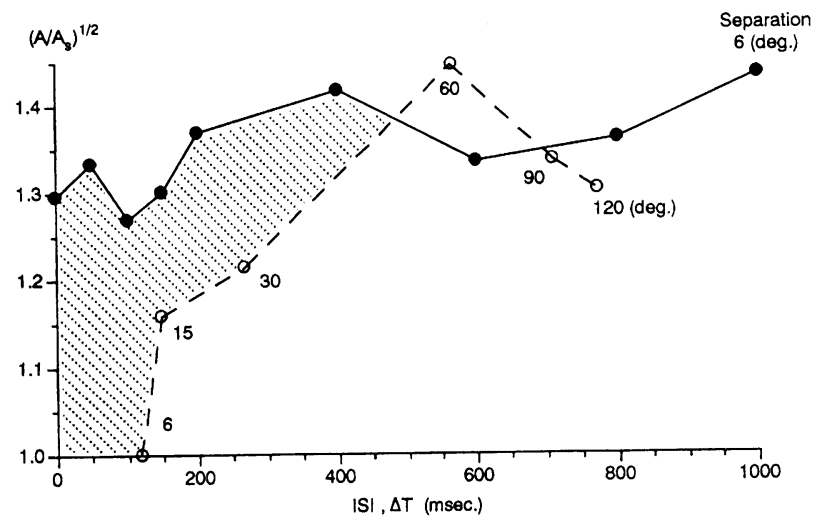

\section{図11 被験者 HS の空間的に離れた刺激配置での等色棈円面積}

$\left(\mathrm{A} / \mathrm{A}_{6}\right)^{1 / 2}$ を視点移動時間 $(\Delta \mathrm{T})$ の関数として再表示し $(O)$ 本実験で得られ た継時呈示での值 $\left(\mathrm{A} / \mathrm{A}_{\mathrm{s}}\right)^{1 / 2}$ ○) と比較した。

Figure 11 Relative values of area $\left(A / A_{6}\right)^{1 / 2}$ obtained by subject $H S$ for spatially separated stimuli as a function of $\Delta T(O)$ and those $\left(A / A_{s}\right)^{1 / 2}$ for temporally separated stimuli as a function of ISI
（四100D）とあわせて表示した。白抜きのシンボルは空間的ギ ヤッブ効果のグラフであるが, 空間間隔 $6^{\circ} \sim 60^{\circ}$ の変化に対して, 視点移動時間 $\Delta \mathrm{T}$ は約 $100 \sim 600 \mathrm{msec}$.の範囲で増大し, 楕円面積 は 1 から 1.4 付近まで上昇している.一方, 空間間隔を $6^{\circ}$ に固定し たままで, 時間間隔だけを変化させたとき（黒シンボル）は 1.4 付 近の值で殆ど変化していない，2つの曲線で，横軸の值が等しい 所では網膜中心䈪に与える刺激の時間的条件は等しいはずであ る。違うのは注視時の網膜周辺に与えられる情報, つまりもう一 方の刺激が呈示されているかどうかである。したがって，斜線部 分が示す弁別能力の差は網膜周辺部の情報の差によるものと考之

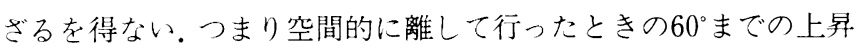
(白シンボル) は, 視点移動による時間的ギャップではなく, 周 辺視の特性に従う。そして $60^{\circ}$ 以上では視野から外れてしまうた め, 弁別能力はあまり変化しないと考之られる。しかし，はたし て片方の色刺激を観察しているときの周辺での色の見えが, 色弁 別に影響を及ばしているのだろうか。そこで次に，その可能性を 探るために，周辺視でのカラーネーミングを試みた。

\section{4 周辺視によるカラーネーミング}

\section{4 .1 実 験}

被験者は HS 1 名. 刺激呈示には本実験と同じ装置を用いた。 ただし, 色彩計の積分管の前面に, 開口のあるマスクを設置し, $0.1^{\circ}$ の固視点を呈示した。対象となる刺激を 7 種類用意した。 その 中の 4 つは本実験で用いた参照刺激である。新たに加えた 3 つは 本実験以外の等色実験で用いた刺激で, 比較的低彩度であるため, 語尾にLow Saturation(LS) を付して区別した。測色值は表 2 に 示与。被験者は固視点に対し正面を向き，それを固視した状態で， 周辺に呈示される 2 正方形の参照刺激を観察し, カラーネーミン グをする。観察は両眼で行なう。何回でも見ることができるが, トラクスラー効果 (固視を続けていると色が消えてゆく現象) ${ }^{11)}$ 避けるため, 1 回の呈示時間は $500 \mathrm{msec}$.とした. 参照刺激の呈示 位置は固視点から左に $6^{\circ}, 15^{\circ}, 30^{\circ}, 60^{\circ}, 90^{\circ} ， 120^{\circ}$ とした。また 参照刺激を固視,つまり中心窩でのカラーネーミングも行なった。 カラーネーミングは, 反对色応答に基づいて知覚量の成分比率を 答える方法である ${ }^{12,13)}$.まず全体を 10 として白み成分, 黒み成分を 答える. 次いで, 赤, 青, 黄, 緑の中から反对色にならないよう に2 色以内を用いて色相を表現する。このときも全体を10として 割合を回答する。例えば, 黒み 1 , 白み 3 (残りは色み 6 ), さら に赤 7 , 黄 3 と答えたとき, 黑成分は 0.1 , 白み成分は 0.3 , 赤成 分は $0.6 \times 0.7=0.42$, 黄成分は $0.6 \times 0.3=0.18$ となる. 各刺激, 各条件に対し, 計 5 回のカラーネーミングを行なった。

表 2 カラーネーミングに用いた参照刺激の測色值（追加分）。

Table 2 Colorimetric value for the reference stimuli for color naming experi ment (addition).

\begin{tabular}{cccc} 
参照刺激 & $\mathrm{x}$ & $\mathrm{y}$ & $\mathrm{Y}\left(\mathrm{cd} / \mathrm{m}^{2}\right)$ \\
\hline Yellow-Green(LS) & 0.529 & 0.378 & 42.2 \\
Orange(LS) & 0.362 & 0.501 & 59.9 \\
Purple(LS) & 0.361 & 0.292 & 46.1 \\
\hline
\end{tabular}

\subsection{2 結 果}

いずれの場合も黒の回答は得られなかった。光源色モードの典 型的な色応答である５回の結果を平均し，図12に表示した。グ ラフは極座標表示で, 中心からの距離は色み成分の大きさを, 角 度方向は色相を表わしている。中心简の結果を大シンボルで表わ

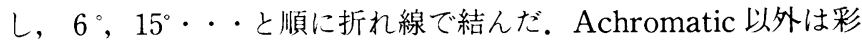
度の変化が見られる。 Yellow-Green, Orange, Purpleといった 


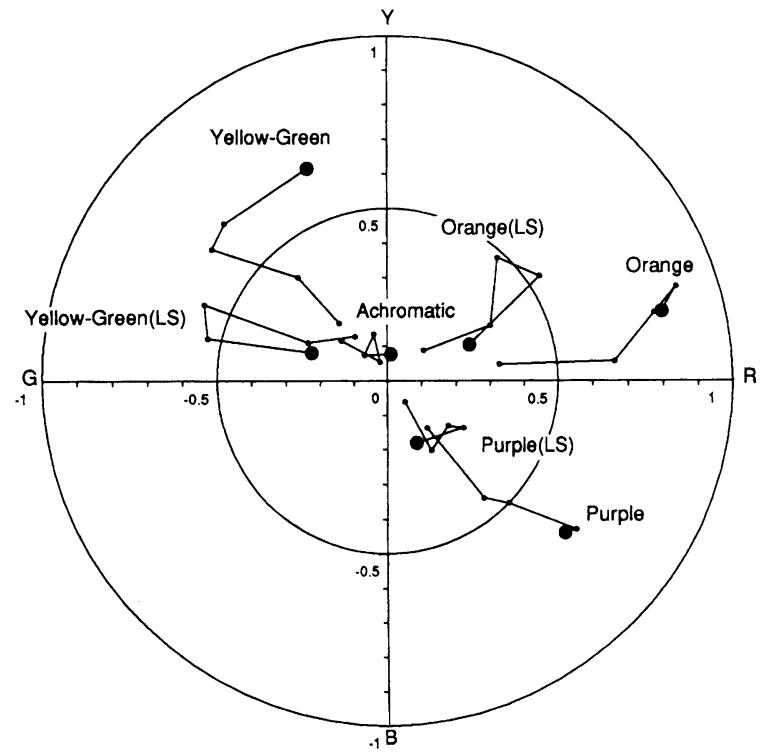

図12 周辺視でのカラーネーミングの結果。

中心からの距離で有彩色成分の量を, 角度方向で色相を示す。大シンボルは中 心䆟での結果を示している。中心窩, 周辺 $6^{\circ} ， 15^{\circ}, 30^{\circ}, 60^{\circ}$ の順に折れ線で結 んだ。

Figure 12 Color naming in peripheral viewing

Radius shows chromatic component and angle shows hue components. The large symbols show results for central viewing. Lines connect points in order of eccentricity.

高彩度の刺激では周辺に行くほど彩度が低下する傾向を示してい る. Yellow-Green(LS), Orange(LS), Purple(LS)といった低彩 度の刺激ではいったん彩度が上昇してから低下する方向へ変化し ている. Purple, Purple(LS) 以外では色相の変化も起きている. さらに Orangeや Purple, Achromatic を除いた刺激では，6。で すでに大きく色の見えが変化している。微細な色の違いを見分け なければならない色弁別作業では，これらの色の見之の変化は致 命的であり，網膜周辺から得た「色情報」を利用しているとは考 えにくい.では色の見之以外の網膜周辺情報の，いったい何が等 色精度や色弁別に効いているのだろうか.これについての議論は, 今後の研究成果を待たなければならない。

\section{5 色弁別メカニズムについて}

小視野 ${ }^{14,15)}$, あるいは低輝度 ${ }^{16)} て ゙$ 見られる色弁別能力の低下と, 我々の扱った笁間ギャップや時間ギャップを伴った呈示法での色 弁別能力の低下では，その原因が本質的に異なると考えている. 前者では網膜レベルで刺激呈示条件の影響を受けている。したが って色の見之（色知覚）自体が暧昧になっており，被験者は“同 じ”に見える(これ以上は違いが分からない) と感じて等色を終 了することができる，以前我々の実験でも，低輝度で等色の繰り 返し精度を測定したときに，精度は大きく低下しているにも拘ら ず，作業にそれほどの苦痛は伴わないという内観報告が得られて いる。 それに対し時空間ギャップのある刺激呈示での色弁別作業 では，色知覚自体ははっきりしているにも拘らず，比較がうまく 出来ないため, “同じ”か“異なる”かの判断をするときに，大き な精神的ストレスが伴う. そのため等色作業も非常に難しく感じ るのである。

我々は後者の, 時空間ギャップのある刺激呈示での弁別能力低 下の原因に関して，次のような色弁別メカニズムを想定して解釈 を試みた。『色弁別は視覚系内の様々なレベルで行なわれ，その処
理レベルによって弁別能力が決まる．また，どのレベルで処理さ れるかは, 刺激の呈示条件によって流動的に決定される』と考え る. 同時呈示で，空間的にも隣接している場合のように最良の条 件では，境界部分から差を直接観察できる。このときの弁別能力 は最も高く，仮にこれを“知覚レベル”での色弁別と呼ぶ．とこ ろが条件が悪くなる，つまり空間的にギャップが入ったり継時呈 示になると，記憶に頼る必要が生じる，すなわち，差を直接知覚 できないため, 知覚している色と記憶している色の比較から差を 引き出さなければならず，弁別能力は低下寸るのである，その延 長線上にあるのが長期記憶による色弁別であり，これを“長期記 憶レベル”での色弁別と呼ぶことにする．2 刺激の間に時空間的 なギャップが存在している条件での色弁別も，この知賞レベルと 長期記憶レベルの間の，どこかのレベルで行われていると考えら れる.このレベルの決定に際して, 周辺網膜からの情報がレベル を知覚レベルの方へ下げる㗢きをしているのではないだろうか. それに対し, 時間的ギャップの大小はレベルの決定に影響しない, その結果等色精度にも変化が現れなかった, と解釈している。し かしこれはあくまで推測であって，客観的根拠に基づくものでは ない.

今後，様々な環境において色差を扱うためには，さらに多様な 刺激呈示条件で色弁別能力を測定し, 色差式や均等色空間に反映 させてゆくことが必要とされる。その際, やみくもに測定するの ではなく, 物理条件の変化が色弁別メカ二ズムの何処に, あるい は何に影響を及ばしているのかを考慮しながら，測定してゆくこ とが重要なのではないだろうか.

\section{5. まとめ}

刺激を継時呈示するときに, 時間的ギャップ(ISI)を 0 から 1000 msec.の範囲で変化させ, 等色の繰り返し精度を測定した. 等色点 のばらつきを xyY 色空間内の楕円体で評価したところ, 棈円体の 大きさはISIによらず一定であった。しかし同時呈示と比べると 明らかな増大が見られ, 注視観察時の網膜周辺情報の重要性が示 唆された。

謝辞

この研究は日本学術振興会特別研究員制度の援助を受けて行な われた。

\section{参 考 文 献}

(1) Witt, K. : Parametric effects on surface colordifference evaluation at threshold, Color Res. Appl., 15 -4, pp.189-199(1990)

(2) Sharpe, L. T. and Wyszecki, G. : Proximity factor in color-difference evaluations, J. Opt. Soc. Am., 66, pp. 40-49(1976)

（3）篠田博之, 池田光男：大きな視点移動を伴う等色作業にお ける繰り返し精度, 照学誌, 78-2, pp.76-82(1994)

(4) Sanders, A. F. : Some aspects of the selective process in the functional visual field, Ergonomics, 13-1, pp.101 $-117(1970)$

(5) Land, M. F. : Predictable eye-head coordination during driving, Nature, 359, pp.318-320(1992)

（6）篠田博之, 池田光男: 等色作業中の視点の動き, 照学誌, 78-10,pp.51-60 (1994) 
(7) Uchikawa, K. and Ikeda, M. : Temporal deterioration of wavelength discrimination with successive comparison method, Vision Res., 21, pp.591-595(1981)

(8) Romero, J., Hita, E. and Jimenez del Barco, L. : A comparative study of successive and simultaneous methods in colour discrimination, Vision Res., 26-3, pp.471-476(1986)

(9) Uchikawa, K. and Ikeda, M. : Accuracy of memory for brightness of colored lights measured with successive comparison method, J. Opt. Soc. Am., A, 3-1, pp.34-39(1986)

(10) Newhall, S. M., Burnham, R. W. and Clark, J. R. : Comparison of successive with simultaneous color matching, J. Opt. Soc. Am.,47-1, pp.43-56(1957)

(11) Clarke, F. J. J. : A study of Troxler's effect, Optica Acta, 7, p.219(1960)

(12) Hård, A. ard Sivik, L. : NCS-Natural color system : A Swedish standard for color notation, Color Res. Appl., 6, pp.129-138(1981)

(13) Gordon, J. and Abramov, I. : Scaling procedures for specifying color appearance, Color Res. Appl., 13-3, pp. 146-152 (1988)

(14) Brown, W. R. J. : The effect of field size and chromatic surroundings on color discrimination, J. Opt. Soc. Am., 42-11,pp. 837-844 (1952)

(15) Bedford, R. E. and Wyszecki, G. W. : Wavelength discrimination for point sources, J. Opt. Soc. Am., 48

\section{-2, pp.129-135(1958)}

(16) Brown, W. R. : The influence of luminance level on visual sensitivity to color differences, J. Opt. Soc. Am., 41-10,pp.684-688(1951)

(受付日1994年 4 月 11 日 / 採録日 1994 年 8 月 4 日)

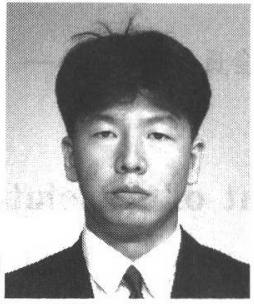

篠苗博之

京都大学工学部

于606-01 京都市左京区吉田本町

昭和 41 年生まれ. 平成元年東京工業大学理学

部物理学科卒, 平成 3 年同大学大学院総合理

工学研究科物理情報工学専攻修士課程修了。 現在は京都大学大学院工学研究科建築学専攻博士後期課程. 専門 は視覚環境，色彩，視覚情報処理。日本視覚学会会員。

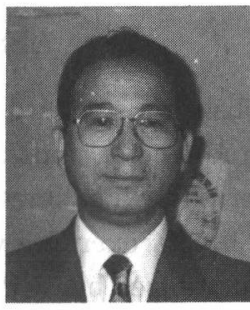

池苗光总 (専門会員)

京都大学工学部建築学教室

干606-01 京都市左京区吉田本町

昭和 30 年大阪大学工学部精密工学科卒業. 昭 和37年米国ロッチェスター大学大学院博士課 程修了, $\mathrm{PhD}$. 東京工業大学教授を経て現在 京都大学工学部建築学教室教授. 視覚情報処理, 色覚, 色彩工学, 色彩環境学の研究と教育に従事. 応用物理学会, 日本色彩学会, 日本建築学会各会員, 日本照明委員会会長, 国際照明委員会第 1 部会長, 国際色彩学会副会長. 